\title{
An Example of a Brief Orientation Program: Students' Adaptation Levels of and Opinions about the Program
}

\author{
Seher A. Sevim * \\ İlhan Yalçın**
}

\begin{abstract}
The purpose of this study was to investigate the effect of a brief orientation program on the adjustment levels of the university first grade students, and to find out their opinions as regards the orientation program. The study was conducted with 321 students who were registered in 2005-06 academic year. 'Adjustment to University Scale' was utilized for determining the adjustment levels and 'Orientation Program Evaluating Questionnaire' for discovering the students' opinions about the program. The findings showed that there is no difference in terms of adjustment levels between the students who attended the orientation program and those who did not attend the program. A great number of students considered the orientation activities useful and necessary as they help them to be familiar with the new surroundings.
\end{abstract}

Key Words: University first grade students, orientation, adjustment

\section{SUMMARY}

For adolescents, stepping in a new life in a university means starting a new period not only in their education careers but also in their family environments. They are to make their own decisions regarding financial

* Assistant professor -Faculty of Educational Sciences, Ankara University

Research Assistant- Faculty of Educational Sciences, Ankara University 
issues, time management etc. In other words, they are expected to become individuals capable of managing themselves almost in every aspect.

A bunch of factors such as level of high school achievement and parental attitudes may affect adolescents' adaptation to university setting. Researches showed that students have low level of adaptation due to environmental reasons as well as personal ones. That is why orientation services are given to the students to help them overcome adjustment problems stemmed from the new environment. Orientation is an activity designed to help individuals manage a better transition from the old environment to the new one. The main objective of orientation programs is to make easier the adjustment process for the freshmen. Such activities also serve as a bridge between the students' old and new educational experiences, which probably have a few common points.

This study investigated the effect of the orientation program on the adjustment levels of the students who started Faculty of Educational Sciences, University of Ankara in 2005. The program was implemented between the $15^{\text {th }}$ and $26^{\text {th }}$ of September 2005. As indicated in the program, students met instructors, watched a cine-vision presentation about the faculty life in general, and were informed about a range of facilities such as library, student communities, medical services as well as cultural and sportive activities. Furthermore, students were taken to specific places in the city.

This paper intended to find out the answers to the following questions:

a. Is there any significant difference between the adjustment levels of the students who participated in the orientation program and the ones who did not participate?

b. What do the students think of the orientation program?

The research group consisted of the $1^{\text {st }}$ class students who enrolled the faculty. A total of 321 students participated in the study, 67 percent of whom were female and 33 percent were male. 24.3 percent of the group were from the department of 'Guidance and Psychological Counseling', 18.7 percent from the department of 'Primary Class Teaching', 17.8 percent from the department of 'Mentally Handicapped Teaching', 13.4 percent from the department of 'Social Studies Teaching', 13.4 percent from the department of 'Pre-School Teaching', and 12.5 percent from the department of 'Computer and Education Technologies Teaching'.

Data gathering tools were applied to the participants during the class hours three weeks after the completion of the orientation program. The 
approximate time for the application was 30 minutes. Adaptation Scale was used to evaluate the views about the orientation program.

The research group was divided into two subgroups, namely the ones who participated in the orientation program and the ones who did not. Orientation program comprised of 12 activities. The students who attended at least six activities formed the 'participating' subgroup. Two subgroups were compared in terms of broad adjustment, social adjustment and academic adjustment. No significant difference was detected $(\mathrm{t}=-.646 \mathrm{p}>.05$ for broad adjustment, $\mathrm{t}=-.446 \mathrm{p}>.05$ for social adjustment and $\mathrm{t}=-.775 \mathrm{p}>.05$ for academic adjustment). These findings suggest that the orientation program implemented in 2005 did not affect the adjustment levels of the students. The result is in agreement with the results of the study done by Martin and Dixon $(1989,1994)$. On the other hand, the results of some other researches indicated that orientation programs help students maintain a higher percentage of attendance and attain a higher level of school achievement (Akbalık, 1997; Brigham and et.al., 1994; Dale and Zych, 1996).

Generally, it was observed that students benefited from every part of the program and students found satisfactory the activities on the emotional dimension. Orientation program was helpful for the students' adaptation processes. However, they stated that the program could include more than mere information giving activities, such as touching upon the practical details of the administrative and educational procedures. Almost half of the students did not take part in the orientation activities. For that reason, orientation programs may be more useful if they are organized a few weeks after the start of the new curriculum year. Since the orientation program did not have a significant effect on the adaptation process of the students, emphasizing psychological elements and academic skills can be taken into consideration in order to achieve a positive impact on the students' transition processes during the planning phases of the future programs. 


\title{
Kısa Süreli Bir Oryantasyon Programı Denemesi: Öğrencilerin Uyum Düzeyleri ve Programa İlişkin Görüşleri
}

\begin{abstract}
Seher A. Sevim*
İlhan Yalçın**

ÖZ: $\mathrm{Bu}$ araştırmanın amacı, kısa süreli bir oryantasyon programının üniversite birinci sınıf öğrencilerinin üniversiteye uyum düzeyleri üzerindeki etkisini incelemek ve öğrencilerin programa ilişkin görüşlerini belirlemektir. Araştırma grubu 2005-2006 eğitimöğretim yılında Ankara Üniversitesi Eğitim Bilimleri Fakültesi’ne kayıt yaptıran 321 öğrenciden oluşmaktadır. Bu çalışmada öğrencilerin uyum düzeyleri "Üniversiteye Uyum Ölçeği”, programa ilişkin görüşleri ise "Oryantasyon Programı Değerlendirme Anketi" ile saptanmıştır. Verilerin analizinde t testi kullanılmıştır. Araştırma sonucunda oryantasyon programına katılan ve katılmayan öğrencilerin üniversiteye uyum düzeyleri arasında anlamlı bir farklılık olmadığı belirlenmiştir. Ayrıca öğrencilerin büyük bir çoğunluğu, etkinliklerden yararlandıklarını, etkinlikleri yeterli bulduklarını ve oryantasyon programının gerekli olduğuna inandıklarını belirtmişlerdir.
\end{abstract}

Anahtar Sözcükler: Üniversite birinci sınıf öğrencileri, oryantasyon, uyum

\section{GíRiş}

Ülkemizde lise öğrencilerinin büyük bir çoğunluğunun amacı, ÖSS'yi kazanarak bir yüksek öğretim programına girebilmektir. Uzun yıllar devam eden yorucu bir sınav maratonunun ardından öğrenciler üniversite yaşamına ilk adımlarını atmaktadırlar. Üniversite birinci sınıf öğrencileri hala ergenlik

* Yrd. Doç.Dr. Ankara Üniversitesi Eğitim Bilimleri Fakültesi

Araş. Gör. Ankara Üniversitesi Eğitim Bilimleri Fakültesi 
dönemindedirler ve yaşamlarında çok sayıda gelişim görevini yerine getirmek durumundadırlar. Üniversiteye giriş, yaşamın yeni bir dönemi olarak görülmektedir. Bu yeni yaşam dönemine uyum sağlamak, genci bekleyen önemli gelişim görevlerinden birisidir. Üniversite yaşamına uyum, gencin okul başarısını da doğrudan etkilemektedir.

Üniversiteye başladığında öğrenciler, yeni bir eğitim ortamına girmekte ve artık aileleri ile ilişkilerinde de yeni bir dönem başlamaktadır. $\mathrm{Bu}$ dönemde öğrenciler; parasal konular, zaman kullanımı ve yaşamın diğer yönleri ile ilgili kararları çoğunlukla kendileri vermektedirler. Böylece onların, kendi kendilerini yöneten bireyler haline gelmeleri beklenmektedir. Öğrencinin yaşamındaki bu değişiklikler aynı zamanda potansiyel risk faktörüdür. Eğer bu gelişim görevlerinden bir ya da daha fazlasında problem ortaya çıarsa, öğrencilerin eğitim hayatı olumsuz yönde etkilenebilmektedir. Öğrencilerin daha önceki yaşam biçimi üniversiteye girdikten sonraki yaşam biçiminden çok farklıysa ve insanlarla etkileşimleri yetersizse, bireylerin üniversiteye uyum süreçlerinde sorunlar ortaya çıkabilir ve bu durum okuldan ayrılmayla bile sonuçlanabilir (Beekhoven, De Song ve Van Hout, 2004).

Üniversite öğrencilerinin uyumlarına ilişkin birçok araştırma yapılmıştır. Baker ve Schultz (1992, akt.Martin ve ark., 1999), üniversitede uyum düzeyleri düşük olan öğrencilerin akademik başarılarının da düşük olduğunu, üniversitenin psikolojik yardım merkezlerine daha çok başvurduklarını ve bu öğrencilerin okulu zamanında bitirme konusunda problem yaşadıklarını belirtmektedirler. Üniversite öğrencilerinin uyum düzeyleri; başa çıkma stratejileri (Jorgensen ve Dusek, 1990), denetim odağı (Martin ve Dixon, 1994), özyeterlik algısı (Silverthorn ve Gekoski, 1995), psikososyal faktörler (Martin ve ark., 1999), akademik başarı ve etnik köken (Strage, 2000), iyi oluş ve kişisel problemler (Beekhoven, De Song ve Van Hout, 2004), kimlik ve rol karmaşası (Killeya-Jones, 2005) gibi değişkenlerle iliş̧isi açısından incelenmiştir. Araştırma bulguları; yurtlarda kalan öğrencilerin, evde kalan öğrencilere göre daha fazla kişisel problem yaşadıklarını, uyum düzeyi yüksek olan öğrencilerin sağlıklı başa çıkma stratejileri kullandıklarını göstermektedir. Ayrıca içten denetimli öğrencilerin dıştan denetimlilere göre üniversiteye daha fazla uyum sağladıklarını, akademik özgüven, üniversiteye ve fakülteye karşı olumlu tutum ve akran desteği değişkenlerinin öğrencilerin üniversiteye uyum sağlama düzeylerini yordadığını göstermektedir.

Üniversite yaşamına uyum sağlamada lise notları, ana baba tutumları gibi bireyin üniversiteye başlamadan önceki özellikleri ve yüksek öğrenim sürecindeki yaşantılarının etkili olabileceği ileri sürülmektedir. Araştırmacılara göre öğrencilerin uyum düzeylerinin düşük olmasında bireysel faktörlerin yanı sıra çevresel faktörlerin de etkisi bulunmaktadır 
(Martin ve ark., 1999; Grayson, 2003). Bu nedenle öğrencilerin yeni girdikleri ortama hem kişisel hem de sosyal uyum sağlamalarına yardım etmek amaciyla oryantasyon hizmetlerinden yararlanılmaktadır. Oryantasyon; bir kuruma yeni gelen bireylere, önceki çevrelerinden yeni girdikleri ortama daha rahat geçiş yapmalarına yardım etmek amacıyla yürütülen çalışmalardır. Oryantasyon programlarının amacı, üniversiteye yeni başlayan öğrencilerin uyum sürecini kolaylaştırmaktır. Oryantasyon çalışmaları üniversite yaşantısının başlangıcında yapıldığı için öğrencilerin geçmiş ve gelecekteki öğrenme yaşantıları arasında bir geçiş unsuru olarak işlev görmektedir. Oryantasyon hizmetleri, öğrencilerin kampüs ve çevresine uyum sağlamaları konusunda önemli bir yere sahiptir. Yeni bir çevreye uyum sağlamanın; sosyal uyum, akademik uyum, kişisel-duygusal uyum, kurumsal bağlılık gibi çeşitli boyutları bulunmaktadır (Martin ve Dixon, 1994). Oryantasyon hizmetleri aracılığı ile akademik, sosyal ve kişiselduygusal uyum ve kurumsal bağlılık boyutlarında öğrencilere yardım edilmesi amaçlanmaktadır. Bu amaçla oryantasyon programı, okuldaki bütün yeni öğrencilere ulaşabilmeli ve okulun sürekli bir faaliyeti olmalıdır. Bunların yanı sıra program ayrıntılı bir şekilde hazırlanmış olmalı, çeşitli faaliyetleri içermeli, tanıma, uyum sağlama ve öğrenme ile ilgili, öğrencilerin gelişim dönemi gereği, daha çok ihtiyaç ve problemler bu etkinliklerin ağırlık merkezini oluşturmalıdır. Programın uygulanmasının ardından ise bir değerlendirme yapılmalı ve programın hedeflere ulaşma derecesi, aksayan ve eksik yönleri saptanmalıdır. Böylece sonraki yıllarda programın geliştirilmesi mümkün olabilir (Yeşilyaprak, 2003).

Oryantasyon programına katılım ile üniversiteye uyum düzeyi arasındaki ilişkiyi inceleyen araştırmaların bulguları arasında farklılıklar göze çarpmaktadır. Goodrich ve Pierson (1959, akt., Martin ve Dixon, 1994) ile Pascarella, Terenzini ve Wolfle'nin (1986, akt., Martin ve Dixon, 1994) çalışmalarında, oryantasyon yaşantısının, öğrencilerin yeni ortamlarındaki çeşitli olumsuz faktörlerle başa çıkma yetenekleri üzerinde etkili olduğu ortaya çıkmıştır. Akbalık (1997) tarafından yapılan araştırmada da üniversite, fakülte, Ankara kenti ve verimli ders çalışma teknikleri ile ilgili bilgilendirme çalışmasının öğrencilerin genel ve sosyal uyumları üzerinde etkili olduğu, buna karşın öğrencilerin akademik uyumlarında anlamlı bir farklılık ortaya koymadığı saptanmıştır. Martin ve Dixon'ın (1989, akt., Martin ve Dixon, 1994) araştırmasında ise oryantasyon programına katılım ile üniversiteye uyum arasında anlamlı bir ilişki bulunmamıştır. Üniversite öğrencilerinin uyum düzeylerini, denetim odağı ve oryantasyon programına katılım açısından inceleyen Martin ve Dixon (1994) ise oryantasyon programına katılımın üniversite öğrencilerinin uyum düzeyleri üzerinde herhangi bir etkisinin olmadığını ortaya koymuşlardır. Gazi Üniversitesi Meslek Eğitim Fakültesinde 1998-1999 Eğitim-Öğretim y1lında yürütülen oryantasyon programının sonucunda öğrencilerin kayıt öncesi ve kayıt 
sirasındaki oryantasyon hizmetlerinden yararlandıkları belirlenmiştir.(Yeşilyaprak ve ark. 1999). Aynı fakültede bir yıl sonra yapılan diğer çalışmada (Yeşilyaprak ve Kısaç, 2002) ise uygulanan oryantasyon programı hem öğrenci hem de öğretim elemanları tarafından olumlu ve etkili olarak değerlendirilmiştir. Boğaziçi Üniversitesi Psikolojik Danışma ve Rehberlik Merkezi'nin hazırlayıp yürüttüŭü "Yükseköğretimde Bir Oryantasyon Denemesi" adlı çalışma sonucunda yeni kayıt olan öğrencilerin \% 30'unun bu programa katıldığı ve katılanların programı olumlu değerlendirdikleri ortaya çıkmıştır (Darcan,1993). Ankara Üniversitesi Eğitim Bilimleri Fakültesi'nde 2004-2005 Eğitim-Öğretim yılı'nda yapılan oryantasyon çalışmasında ise öğrencilerin büyük çoğunluğu değişik derecelerde de olsa etkinlikleri yeterli bulduklarını ifade etmişlerdir. Öğrencilerin duyuşsal boyutta yer alan etkinlikleri genellikle yeterli olarak değerlendirdikleri gözlenirken, bilgi aktarımına dayalı etkinliklerin öğrenciler tarafından yetersiz olarak algılandığı tespit edilmiştir (Yeşilyaprak ve ark., 2005).

Bu çalışmada Ankara Üniversitesi Eğitim Bilimleri Fakültesi'ne 20052006 Eğitim-Öğretim yılında yeni kayıt yaptıran öğrencilere sunulan oryantasyon hizmetlerinin, öğrencilerin uyum düzeyleri üzerindeki etkisi incelenmiştir. Oryantasyon programı 15-26 Eylül 2005 tarihleri arasında düzenlenmiştir. Program kapsamında; öğrencilerin bölümlerin öğretim personeli ile tanışmaları sağlanmış, üniversite ve fakülteyi tanıtan sinevizyon gösterisi düzenlenmiş, öğrenci toplulukları tanıtım ve gösteriler düzenlemiş, sağlık, kültür ve spor işleri dairesi, kütüphane, öğrenci işleri ve fakültenin birim ve merkezleri tanıtılmıştır. Bunlara ek olarak Ankara'nın belirli merkezlerine gezi düzenlenmiş ve Prof. Dr. Üstün Dökmen tarafından bir konferans verilmiştir. $\mathrm{Bu}$ araştırmada uygulanan programın değerlendirilmesine yönelik olarak aşağıdaki sorulara yanıt aranmıştır.

a) Oryantasyon programına katılan ve katılmayan öğrencilerin uyumları arasında istatistiksel açıdan manidar bir farklılık var mıdır?

b) Öğrencilerin oryantasyon programına ilişkin görüşleri nelerdir?

\section{YÖNTEM}

\section{Araştırma Grubu}

Oryantasyon programı, Ankara Üniversitesi, Eğitim Bilimleri Fakültesi'ne 2005-2006 öğretim yılında kayıt yaptıran birinci sınıf öğrencilerine yönelik olarak planlanmıştır. Fakültenin açıldığı ilk hafta öğrencilerin kalacak yer arama, burs-kredi gibi olanakları araştırma.vb. nedenlerle programın devam ettiği hafta boyunca öğrencilerin etkinliklere katılım oranları da değişmiştir. 
Programın değerlendirilmesi, oryantasyon uygulamasından üç hafta sonra birinci sınıf öğrencilerine değerlendirme anketi ve uyum ölçeği uygulanarak yapılmıştır. Veriler, anketlerin uygulandığı sırada sinıflarda bulunan öğrenci sayısı ile sınırlıdır. Araştırma grubu 321 öğrenciden oluşmaktadır. Grubun \%67'si kız öğrenci, \%33'ü erkek öğrencilerden meydana gelmiştir. Grubun \% 24.3'ü Rehberlik ve Psikolojik Danışma Programı, \%18.7'si Sınıf Öğretmenliği, \%17.8'i Zihin Engelliler Öğretmenliği, \%13.4'ü Sosyal Bilgiler Öğretmenliği, \%13.4'ü Okul Öncesi Öğretmenliği \%12.5'i Bilgisayar ve Öğretim Teknolojileri Eğitimi bölümünde okumaktadır. Üniversiteye başlayıncaya kadar öğrencilerin \%38'i ilçelerde, \%23.7'si küçük kentlerde, \%38.3'ü büyük kentlerde (metropollerde) yaşamıştır.

\section{İşlem}

Oryantasyon programının uygulaması bittikten üç hafta sonra, birinci sınıfların ders saati içerisinde uygulama yapılmıştır. Oryantasyon programına ilişkin görüşlerini almak amacıyla anket ve uyumlarını değerlendirmek için Uyum ölçeği uygulanmıştır. Uygulama yaklaşık 30 dakika sürmüştür.

\section{Veri Toplama Araçları}

1. Oryantasyon Programı Değerlendirme Anketi: Programı değerlendirmek amaciyla, benzer programlar için geliştirilmiş olan anketten yararlanılmıştır (Yeşilyaprak ve ark 1999). Ankette bazı kısaltma ve değişiklikler yapılarak, uygulanan oryantasyon programına ilişkin öğrenci görüşleri alınmıştır. Ankette oryantasyon programında yer alan etkinlikler sıralanmıştır ve öğrenciler "hiç/az yararlandım, yararlandım ve oldukça/çok yararlandım" şeklinde görüşlerini belirtmişlerdir. Ayrıca öğrencilerin hangi etkinliklere katıldığı da sorulmuştur.

2. Üniversiteye Uyum Ölçeği: Akbalık (1997), tarafından üniversite öğrencilerinin akademik çevreye uyumlarını değerlendirmek amacıyla geliştirilmiştir. Sosyal uyum ve akademik uyum olmak üzere iki alt boyuttan oluşan ölçekte toplam 31 madde bulunmaktadır. Sosyal uyumla ilgili faktörde bulunan maddelerin faktör yükleri .33 ile .68 , akademik uyum alt boyutunda ise .60 ile .82 arasında değişmektedir. İki faktörün toplam açıkladığı varyans oranı \%35.8'dir. Ölçeğin Sosyal Uyum alt ölçeğinin Hacettepe Kişilik Envanteri'nin Sosyal İlişkiler alt ölçeği ile aralarındaki ilişki $\mathrm{r}=.75(\mathrm{p}<.01)$ tir. $\mathrm{Bu}$ sonuç ölçüt geçerliğinin kanıtı olarak değerlendirilmiştir. Uyum ölçeğinin güvenirlik katsayıları tüm ölçek için .90, Sosyal Uyum .82 ve Akademik Uyum için .91 olarak bulunmuştur. 


\section{Oryantasyon Programı ve Uygulama}

Oryantasyon programı çalışmaları, bu programda görev alacak kişilerin belirlenmesi ile başlamıştır. Çalışmalar sonucunda, her bölümden iki araştırma görevlisi yürütme kurulunu ve PDR Ana Bilim dalından üç öğretim elemanı danışma kurulunu oluşturmuştur. Uygulama sürecinin değerlendirme çalışmasını yapan ve raporlaştıran kişiler de uygulamaların planlanması ve yürütülmesi sürecinde yer almışlardır. Çalışmalar, fakültenin eğitim-öğretim işlerinden sorumlu Dekan yardımcısının koordinatörlüğünde yürütülmüştür. Koordinatör, danışma kurulu ve yürütme kurulunun düzenli toplanması yoluyla etkinlikler planlanmıştır. Etkinlikler iki aşamada gerçekleştirilmiştir.

\section{Kayıt sirasinda yapılan etkinlikler:}

Fakültede kayıt sırasında danışma masası olușturulması: Her bölümün kayıt işlemleri farklı günlerde yapılmıştır. Kayıt günü ilgili bölümden görevli birinci sınıf danışmanları, danışma masalarında durarak öğrencilerden gelen soruları cevaplamışlardır. Ö ğrencilere fakültenin açıldığı ilk gün, her bölüm tarafından yapılacak olan bilgilendirme toplantısının saati duyurulmuştur.

\section{Fakültenin açıldiğı ilk hafta yapılanlar:}

1. Ders kayıtlarının yapılması

2. Öğrencilerle tanışma ve bilgilendirme

3. Kütüphane hizmetlerinin uygulamalı tanıtımı

4. Ankara' yı tanitım turu ve Anitkabir ziyareti

5. Üniversiteyi ve Fakülteyi tanıtım toplantısı

6. Prof. Dr. Üstün Dökmen'in konferans1-"Yaşamı Tatmak ve Tatlandirmak"

\section{BULGULAR ve TARTIŞMA}

Oryantasyon programında 12 etkinlik bulunmaktadır. Yukarıda altı etkinlik belirtilmiştir. Diğer altı etkinlik ise "Üniversiteyi ve fakülteyi tanıtım etkinliğinin" içinde yer almaktadır. Öğrenciler etkinliklerden bir kısmına katılırken, çeşitli nedenlerle bir kısmına katılmamışlardır. 12 etkinlikten en az altı etkinliğe devam edenler "katılan grubu" meydana getirmiştir. Altı etkinlikten daha azına katılanlar ise oryantasyon programına devam etmeyen grup olarak sınıflandırılmıştır. Öğrencilerin Üniversiteye Uyum Ölçeği'nden aldıkları puanlara ilişkin aritmetik ortalama ve standart sapma değerleri Tablo 1'de verilmiştir. 
Tablo 1. Araştırmaya katılan öğrencilerin Üniversiteye Uyum Ölçeği'nden aldıkları puanlara ilişkin $\mathrm{N}, \overline{\mathrm{X}}$ ve ss değerleri

\begin{tabular}{|c|c|c|c|c|c|c|c|}
\hline \multirow{2}{*}{ Gruplar } & \multirow{2}{*}{$\mathbf{N}$} & \multicolumn{2}{|c|}{ Genel Uyum } & \multicolumn{2}{|c|}{ Akademik Uyum } & \multicolumn{2}{|c|}{ Sosyal Uyum } \\
\hline & & $\bar{X}$ & ss & $\bar{X}$ & ss & $\bar{X}$ & ss \\
\hline & 186 & 99.18 & 14.80 & 17.31 & 5.23 & 81.87 & 12.62 \\
\hline Katılmayan & 135 & 100.32 & 16.99 & 17.77 & 5.27 & 82.54 & 14.48 \\
\hline
\end{tabular}

Tablo 1'de görüldüğü gibi öğrencilerin genel uyum, sosyal uyum ve akademik uyum puanlarının aritmetik ortalama değerleri arasında oldukça küçük bir fark bulunmaktadır. Araştırmanın birinci sorusunu incelemek için katılan ve katılmayan grubun genel uyum, sosyal uyum ve akademik uyum açısından farklılaşıp farklılaşmadığı $\mathrm{t}$ testi ile incelenmiştir. İki grubun genel uyum ( $\mathrm{t}=-.646 \mathrm{p}>.05)$, ayrica sosyal uyum $(\mathrm{t}=-.446 \mathrm{p}>.05)$ ve akademik uyum ( $\mathrm{t}=-.775 \mathrm{p}>.05)$ açısından da farklı olmadığı belirlenmiştir. $\mathrm{Bu}$ bulgulardan yola çıkarak, uygulanan Oryantasyon programının öğrencilerin uyum düzeyi üzerinde manidar bir fark yaratmadığı söylenebilir. Bu sonuç Martin ve Dixon'ın (1989, 1994) yaptıkları çalışmaların sonuçlarıyla benzerdir. Oysa literatürdeki bazı araştırma sonuçlarına göre, oryantasyon programları öğrencilerin okula devam etmesine katkı sağlamakta ve okul başarısını olumlu yönde etkilemektedir (Akbalık,1997; Brigham ve ark.,1994; Dale ve Zych, 1996). Öğrencilerin uyumu ve okul başarısı üzerinde olumlu etkisi olduğu belirlenen programlar incelendiğinde (Brigham ve ark., 1994; Dale ve Zych, 1996), problem çözme becerilerini öğretme, etkili çalışma becerilerini geliştirme, öğrencilerin akademik ilerlemelerini ve sorunlarını izleme, öğrencilere maddi yardımlar sağlama, akran desteğinden yararlanma, kültürel programlara katılma, stres yönetimi gibi bir çok öğeyi içerdiği belirlenmiştir. Bu programlar akademik başarıyı arttırmak için gerekli etkili çalışma becerileri yanında, kişilerarası ilişki ve kendini tanıma konusuna odaklaşmakta ve bireyi tüm yönleriyle geliştirmeyi amaçlamaktadır. Oysa Eğitim Bilimleri Fakültesinde uygulanan program hem içerik hem de süre açısından farklıdır. Kısa süreli ve daha çok tanıtıma ağırlık veren bir programdır. Programın öğrencilerin akademik ve sosyal uyumunu etkilememesinin bu durumdan kaynaklandığı düşünülebilir. Ayrıca programın tümüne katılmamaları da öğrencilerin yararlanma düzeylerini etkilemiş olabilir. Uyum sonuçlarını etkileyebilecek bir diğer konu ise, uygulamadan üç hafta sonra değerlendirmenin yapılmış olmasıdır. Programın etkileri daha uzun vadede ortaya çıkabilir. Ayrıca program 
uygulanmadan önce öğrencilerin uyum düzeylerinin belirlenmesi de programı daha sağlıklı bir şekilde değerlendirmeyi sağlayabilir.

Araştırmanın ikinci sorusuna cevap verebilmek amacıyla öğrencilerin ankete verdikleri yanıtlar üç kategori halinde yüzde ve frekanslar şeklinde tablolaştırılmıştır. Birinci bölümde programda yer alan etkinliklerden yararlanmaya ilişkin sorular bulunmaktadır. Tablo 2'de bu sorulara verilen cevaplar bulunmaktadır.

Tablo 2. Öğrencilerin Oryantasyon Programı Etkinliklerinden Yararlanma Durumlarına İlişkin Görüşlerin Dağı̆lımı

\begin{tabular}{|c|c|c|c|c|c|c|c|c|}
\hline \multirow[t]{2}{*}{ Etkinlikler } & \multicolumn{2}{|c|}{ Katılmadım } & \multicolumn{2}{|c|}{$\begin{array}{l}\mathrm{Hiç/Az} \\
\text { yaralandım }\end{array}$} & \multicolumn{2}{|c|}{ Yararlandım } & \multicolumn{2}{|c|}{$\begin{array}{c}\text { Oldukça } \\
\text { /Çok } \\
\text { yararlandım }\end{array}$} \\
\hline & $\mathrm{f}$ & $\%$ & $\mathrm{f}$ & $\%$ & $\mathrm{f}$ & $\%$ & $\mathrm{f}$ & $\%$ \\
\hline 1.Danışma masalarının çalışması & 65 & 20.2 & 98 & 38.3 & 142 & 55.5 & 16 & 6.2 \\
\hline 2. Bölümlerdeki bilgilendirme ve tanışma toplantısı & 141 & 43.9 & 43 & 23.9 & 113 & 62.8 & 24 & 13.3 \\
\hline 3. Üniversite ve fakülteyi tanıtan sinevizyon gösterisi & 158 & 49.2 & 38 & 23.3 & 106 & 65 & 19 & 11.7 \\
\hline $\begin{array}{l}\text { 4. Dekanın açış konuşması ve fakülte ile ilgili } \\
\text { açıklamalar }\end{array}$ & 152 & 47.4 & 43 & 25.4 & 102 & 60.4 & 24 & 14.2 \\
\hline 5. Öğrenci topluluklarının tanıtımı & 184 & 57.3 & 66 & 48.2 & 54 & 39.4 & 17 & 12.4 \\
\hline 6.Öğrenci topluluklarının gösterileri & 180 & 56.1 & 27 & 19.1 & 82 & 58.2 & 32 & 22.7 \\
\hline 7. Sağlık, kültür ve spor işleri dairesinin tanıtımı & 175 & 54.5 & 38 & 26 & 85 & 58.2 & 23 & 15.8 \\
\hline 8.Kütüphanenin tanıtımı & 198 & 61.7 & 29 & 26 & 85 & 58.2 & 23 & 15.8 \\
\hline 9.Öğrenci işlerinin tanıtımı & 158 & 49.2 & 62 & 38 & 91 & 55.8 & 10 & 6.1 \\
\hline 10. Fakültenin ilgili birim ve merkezlerinin tanıtımı & 150 & 46.7 & 59 & 34.5 & 98 & 57.3 & 14 & 8.2 \\
\hline 11. Şehir turu ve Anıtkabir ziyaretinin düzenlenmesi & 132 & 41.1 & 39 & 20.6 & 96 & 50.8 & 54 & 28.6 \\
\hline 12. Prof. Dr. Üstün Dökmen'in Konferans1 & 117 & 36.4 & 4 & 2 & 51 & 25 & 149 & 73 \\
\hline
\end{tabular}

Tablo 2 incelendiğinde, öğrencilerin büyük çoğunluğu değişik derecelerde de olsa etkinliklerden yararlandıklarını ifade etmişlerdir. Oryantasyon programında yer alan etkinlikler içinde öğrencilerin en fazla yararlı buldukları etkinlikler aşağıda sıralanmıştır. (yararlandım ve çok yararlandım sütunlarının toplamlarına göre) :

1. Prof. Dr. Üstün Dökmen'in konferansı $(\% 98,1)$

2. Öğrenci topluluklarının gösterileri (\%80.9)

3. Şehir turu ve Anıtkabir Ziyareti $(\% 79,4)$

4. Bölümlerdeki bilgilendirme ve tanışma toplantısı (\%76.1)

5. Üniversite ve fakülteyi tanıtan sinevizyon gösterisi(\%76.7) 

\%74.6)

6. Dekanın açış konuşması ve kütüphanenin tanıtımı ( \%74.6 ve

Öğrencilerin duyuşsal boyutta yer alan etkinlikleri genellikle yararlı olarak değerlendirdikleri gözlenmektedir. Özellikle Prof. Dr. Üstün Dökmen'in konuşması en fazla beğenilen ve yararlanılan etkinliktir. Sırasıyla öğrenci topluluklarının gösterileri, şehir turu, bölüm ile ilgili açıklamalar ve sinevizyon gösterisi de öğrenciler tarafından yararlanıldığı ifade edilen etkinlikler arasındadır.

Öğrenciler tarafından daha az yararlı bulunan etkinlikler aşağıda sırasıyla verilmiştir.

1. Öğrenci topluluklarının tanıtımı $(\% 48,2)$

2. Danışma masalarının çalışması (\%38.3)

3. Öğrenci işlerinin tanıtımı (\%38)

4. Fakültenin ilgili birim ve merkezlerinin tanıtımı (\%34.5)

Öğrencilerin \%48,2'si öğrenci topluluklarının masalar oluşturularak tanıtımını yetersiz bulmuşlardır. Yetersiz bulunan etkinlikler \%38.3 ile kayıt esnasında danışma masalarının çalışması ve \%38 ile öğrenci işlerinin tanitımidir.

Öğrenci topluluklarının gösterileri en fazla beğenilen ve yararlanılan etkinlik olarak belirtilirken, öğrenci topluluklarının tanıtımı yetersiz bulunmuştur. Yetersiz bulunan etkinliklerin genellikle bilgi verme ağırlıklı olduğu saptanmıştır. Daha önceki yıllarda sadece bilgi aktarımı şeklinde yapılan kütüphanenin tanıtım biçimi 2005 yılındaki uygulamada değiştirilmiştir. Öğrenciler kütüphaneye gruplar halinde götürülerek uygulamalı bir tanıtım yapılmıştır. Kütüphaneyi tanıtım biçimindeki bu değişim, öğrencilerin değerlendirmelerine yansımıştır ve öğrencilerin \%76's1 kütüphane tanıtımından yararlandığını belirtmiştir. Aslında öğrencilerin bazı birimleri tanıması, ilgili birimlerle etkileşim içine girince daha kolay olmaktadır. $\mathrm{Bu}$ yüzden bazı bilgilerin zaman içerisinde kazanılacağını söylemek yanlış olmayacaktır.

Öğrencilerin düzenlenen etkinliklerin organizasyonu ve etkililiği açısından yeterli olup olmadığına ilişkin görüşleri Tablo 3'te sunulmaktadır. 
Tablo 3. Öğrencilerin Oryantasyon Programı Etkinliklerinin Yeterliğine İlişkin Görüşlerinin Dağılımı

\begin{tabular}{|c|c|c|c|c|c|c|c|c|}
\hline \multirow[t]{2}{*}{ Görüşünüz } & \multicolumn{2}{|c|}{$\begin{array}{l}\text { Yetersiz/Az } \\
\text { Yeterli }\end{array}$} & \multicolumn{2}{|c|}{ Yeterli } & \multicolumn{2}{|c|}{$\begin{array}{l}\text { Oldukça/Çok } \\
\text { Yeterli }\end{array}$} & \multicolumn{2}{|c|}{ Toplam } \\
\hline & $\mathrm{f}$ & $\%$ & $\mathrm{f}$ & $\%$ & $\mathrm{f}$ & $\%$ & $\mathrm{f}$ & $\%$ \\
\hline 1.Danışma masaları & 66 & 34.7 & 123 & 64.7 & 1 & .5 & 190 & 100 \\
\hline $\begin{array}{l}\text { 2. Üniversite ve fakülteyi tanıtan } \\
\text { sinevizyon gösterisi }\end{array}$ & 54 & 28.1 & 117 & 60.9 & 21 & 10.9 & 192 & 100 \\
\hline $\begin{array}{l}\text { 3. Bölümlerdeki bilgilendirme ve } \\
\text { tanışma toplantısı }\end{array}$ & 58 & 31.2 & 103 & 55.4 & 25 & 13.4 & 186 & 100 \\
\hline $\begin{array}{l}\text { 4. Programda görev alan kişilerin } \\
\text { tutum ve davranışları }\end{array}$ & 23 & 12.0 & 106 & 55.2 & 63 & 32.8 & 192 & 100 \\
\hline $\begin{array}{l}\text { 5. Oryantasyon programının } \\
\text { süresi }\end{array}$ & 49 & 25.7 & 96 & 50.3 & 46 & 24.1 & 191 & 100 \\
\hline $\begin{array}{l}\text { 6.Etkinliklerin program süresi } \\
\text { içindeki dağılımı }\end{array}$ & 59 & 30.9 & 101 & 52.9 & 31 & 16.2 & 191 & 100 \\
\hline 7. Programın düzenlendiği günler & 45 & 23.7 & 113 & 59.5 & 32 & 16.8 & 190 & 100 \\
\hline 8.Programın düzenlendiği saatler & 31 & 16.2 & 130 & 68.1 & 30 & 15.7 & 191 & 100 \\
\hline $\begin{array}{l}\text { 9.Sosyal etkinliklerin(Ankara } \\
\text { turu, öğrenci toplulukları ) } \\
\text { yeterliliği }\end{array}$ & 57 & 30.0 & 89 & 46.8 & 44 & 23.2 & 190 & 100 \\
\hline
\end{tabular}

Tablo 3 incelendiğinde, öğrencilerin programdaki etkinliklere ilişkin görüşlerinin genellikle olumlu olduğu görülmektedir. Ancak kayıt sırasında kurulan danışma masaları öğrenciler tarafından (\%34.7) yetersiz bulunmuştur. Bunu sirasılyla Bölümlerdeki bilgilendirme (\%31.2), etkinliklerin program içindeki dağılımı (\%30.9) ve sosyal etkinlikler-Ankara turu ve topluluk gösterileri (\%30) izlemektedir. Bölümlerdeki bilgilendirme ve sosyal etkinlikler-Ankara turu ve topluluk gösterileri en fazla yararlanılan etkinlikler arasında olmalarına rağmen, grubun \%30'u bu etkinlikleri yeterli bulmamışlardır. $\mathrm{Bu}$ etkinliklerin niteliğinin veya süresinin gözden geçirilmesinin yararlı olacağı düşünülmektedir. 
Tablo 4. Öğrencilerin Oryantasyon Programına Yönelik Duygu ve Düşüncelerinin Dağılımı

\begin{tabular}{|c|c|c|c|c|c|c|c|c|}
\hline \multirow[t]{2}{*}{ Görüşünüz } & \multicolumn{2}{|c|}{ Hayır } & \multicolumn{2}{|c|}{ Kismen } & \multicolumn{2}{|c|}{ Evet } & \multicolumn{2}{|c|}{ Toplam } \\
\hline & $\mathrm{f}$ & $\%$ & $\mathrm{f}$ & $\%$ & $\mathrm{f}$ & $\%$ & $\mathrm{f}$ & $\%$ \\
\hline $\begin{array}{l}\text { Oryantasyon } \quad \text { programı } \\
\text { bölümlerinizi (öğretim elemanları, dersler vb) } \\
\text { tanıdığınızı düşünüyor musunuz? }\end{array}$ & 19 & 9.2 & 138 & 67 & 49 & 23.8 & 206 & 100 \\
\hline $\begin{array}{l}\text { 2. Program sayesinde üniversite yaşantısı ile } \\
\text { ilgili merak ettiğiniz sorulara yanıt bulabildiniz } \\
\text { mi?. }\end{array}$ & 26 & $\begin{array}{l}12 . \\
6\end{array}$ & 145 & 70.4 & 35 & 17 & 206 & 100 \\
\hline $\begin{array}{l}\text { 3. Program, yeni ortamınızda kendinizi iyi } \\
\text { hissetmenize yardımcı oldu mu? }\end{array}$ & 30 & $\begin{array}{l}14 . \\
6\end{array}$ & 81 & 39.3 & 95 & 46.1 & 206 & 100 \\
\hline $\begin{array}{l}\text { 4. Program boyunca hoş karşılandığınız } \\
\text { duygusunu yaşadınız } \mathrm{m} \text { ? }\end{array}$ & 22 & 10. & 65 & 31.6 & 119 & 57.8 & 206 & 100 \\
\hline $\begin{array}{l}\text { 5. Program süresince yeni arkadaşlar edindiniz } \\
\text { mi? }\end{array}$ & 16 & 7.9 & 41 & 20.2 & 146 & 71.9 & 203 & 100 \\
\hline $\begin{array}{l}6 \text { Oryantasyon programının yeni eğitim ortamına } \\
\text { uyum sağlamanıza katkısı oldu mu? }\end{array}$ & 13 & 6.3 & 94 & 45.9 & 98 & 47.8 & 205 & 100 \\
\hline $\begin{array}{l}7 \mathrm{Bu} \text { tür programların gerekliliğine inanıyor } \\
\text { musunuz? }\end{array}$ & 5 & 2.5 & 20 & 10 & 175 & 87.5 & 200 & 100 \\
\hline
\end{tabular}

Tablo 4'te görüldüğü gibi öğrenciler programda yer alan etkinliklere yönelik duygu ve düşüncelerini "hayır, kısmen ve evet" şeklinde belirtmişlerdir. Ankete katılan öğrencilerin \%87.5'i programın gerekliliğine inandıklarını belirtirken, \%71.9'u program süresince yeni arkadaşlar edindiklerini, \%57.8'i program boyunca kendileriyle ilgilenildiğini ve $\% 46.1$ 'i programın yeni ortamlarında kendilerini iyi hissetmelerine yardımcı olduklarını ifade etmişlerdir.

Oryantasyon programlarının yararlarından birisi, öğrencilerin uyum sürecini kolaylaştırmaktır. Öğrencilerin yeni arkadaş edindiklerini ve kendileriyle ilgilenildiği duygusunu yaşadıklarını söylemeleri bu amaca kısmen de olsa ulaşıldığının bir göstergesi olarak yorumlanabilir. Yine benzer bir şekilde öğrencilerin \%46.1'inin, programın fakülte ortamında kendisini iyi hissetmesine yardımcı olduğunu belirtmesi yukarıdaki bulguları desteklemektedir. Öğrenciler bölüm ile ilgili açıklamaların yetersiz olduğu şeklinde görüş belirtmişlerdir. Ancak ilk ay içerisinde bölüm ve derslerle ilgili bilgi eksikliği tamamlanamamaktadır. Bilgi eksikliğini gidermek açısından özellikle öğrenci danışmanlarına önemli görevler düşmektedir. Belirli aralıklarla düzenli toplantılar yapılarak bölüm ve dersler ile ilgili yetersizlikler tamamlanabilir. 


\section{SONUÇ}

Bu çalışmada, Ankara Üniversitesi Eğitim Bilimleri Fakültesi birinci sınıf öğrencilerine 2005-2006 öğretim yılı başında uygulanan oryantasyon programının yeterliliğine ilişkin öğrenci görüşleri ile programın akademik ve sosyal uyum üzerindeki etkisi belirlenmiştir.

Genel olarak bakıldığında öğrencilerin oryantasyon programının her aşamasından yararlandıkları, özellikle de öğrencilerin duyuşsal boyutta yer alan etkinlikleri genellikle yeterli olarak değerlendirdikleri gözlenmektedir. Oryantasyon Programı, öğrencilerin okula alışmaları, fakültenin etkinliklerini kavramaları açısından işlevsel olmuş, öğrenciler bu programdan olumlu olarak etkilenmişlerdir. Ancak öğrencilerin bilgi verme ve tanıtım ağırlıklı etkinlikleri yetersiz buldukları görülmektedir. Eğitimöğretim konusu gibi mevzuat bilgilendirmesinin ayrıntılı yapılmasının ve ayrıca fakültenin birimlerinin işleyişi, öğrencilerin bu birimlerden nasıl yararlanabilecekleri gibi bilişsel konuların üzerinde daha yoğun durulmasının uygun olduğu düşünülmektedir. Bilgilendirme toplantılarının öğrencilerin fakülte ortamına alıştığı ilk birkaç hafta sonunda yapılması da düşünülebilir. Oryantasyon etkinliklerine fakülteye kayıt yaptıran öğrencilerin neredeyse \%50'sinin katılamadığı belirlenmiştir. Gelecek y1l programın uygulama tarihinin değiştirilmesi daha çok öğrencinin katılmasını sağlayabilir. Programın bu haliyle ilk hafta uygulanması öğrencilerin katılımını güçleştirmektedir.

Uygulanan programın, öğrencilerin uyumu üzerinde etkili olmadığı saptanmıştır. Üniversitelerde öğrencilere yönelik eğitim ve öğretim dışında kalan tüm hizmetler "Sağlık, Kültür ve Spor Daire Başkanlığı"nca verilmektedir. Üniversiteye yeni başlayan öğrencilere üniversite, kurallar, yönetmelikler ve yakın çevre hakkında tanıtıcı ve aydınlatıcı bilgiler vermek bu başkanlığın görevleri arasındadır. Ancak uygulamada bu hizmetlerin yeterince verilmediğini söylemek yanlış olmayacaktır. Oryantasyon etkinlikleri Sağlık, Kültür ve Spor Daire Başkanlıkları tarafından üniversitedeki tüm öğrencilere yönelik olarak düzenlenebilir.

Öğrencilerin uyum sürecini etkileyebilecek psikolojik öğelerin ağır bastığı, akademik becerileri arttırmaya önem veren daha uzun süreli çalışmaların Psikolojik Danışma Birimlerince planlanması yararlı olacaktır. Ancak bu tür çalışmalar çok sayıda Psikolojik Danışma uzmanının çalıştığı merkezler yoluyla yapılmalıdır ve birinci sınıf öğrencilerine yönelik yıl boyunca eğitsel ve kişisel-sosyal rehberlik kapsamında etkinlikler düzenlenmelidir. $\mathrm{Bu}$ tür çalışmaları yapabilmek için Üniversitemizdeki Psikolojik Danışma ve Rehberlik Merkezlerinin yeniden yapılandırılması, işlevlerinin gözden geçirilmesi ve bütün kampüslere yaygınlaştırılması gereklidir. 


\section{KAYNAKLAR}

Akbalık, G. (1997). Bilgilendirme ve grupla psikolojik danışmanın üniversite öğrencilerinin üniversiteye uyumlarına etkisi. (Yayınlanmamış doktora tezi), Ankara: Ankara Üniversitesi.

Beekhoven, S., De Song, U., ve Van Hout, H. (2004). The impact of firstyear students' living situation on the integration process and study progress. Educational Studies, 30(3), 277-290.

Brigham, T. A., Moseley, S. A., Sneed, S. ve Fisher, M. (1994). Excel: An intensive and structured program of advising and academic support to assist minority freshman to succeed at a large state university. Journal of Behavioral Education. 4(2), 227-242.

Dale, P. M., ve Zych, T.(1996). A successful college retention program, College Student Journal, 30, 354-360.

Darcan, A. (1993). Yükseköğretimde bir oryantasyon programı denemesi, II. Ulusal Psikolojik Danışma ve Rehberlik Kongresi, 27-29 Eylül, Ankara:Hacettepe Üniversitesi.

Grayson, J. P. (2003). The consequences of early adjustment to university, Higher Education ,46, 411-429.

Jorgensen, R. S. ve Dusek, J. B. (1990). Adolescent adjustment and coping strategies. Journal of Personality, 58 (3), 503-513.

Killeya-Jones, L. A. (2005). Identity structure, role discrepancy and psychological adjustment in male college student-athletes. Journal of Sport Behavior, 28 (2), 167-185.

Martin, Jr. ve ark. (1999). Psychosocial factors that predict the college adjustment of first-year undegraduate students: Implications for college counselors. Journal of College Counseling, 2 (2), 121-134.

Martin, N. K., ve Dixon, P. N. (1994). The effects of freshman orientation and locus of control on adjustment to college: A follow-up study. Social Behavior and Personality, 22 (2), 201-208.

Silverthorn, N. A. ve Gekoski, W. L. (1995). Social desirability effects on measures of adjustment to university, independence from parents, and self-efficacy. Journal of Clinical Psychology, 51 (2), 244-251.

Strage, A. (2000). Predictors of college adjustment and succes: Similarities and differences among southeast-asian-american, hispanic and white students. Education, 120 (4), 731-740. 
Yeşilyaprak, B. ve ark. (1999). 1998-1999 öğretim yılı G. Ü. Mesleki Eğitim Fakültesi oryantasyon programı: Uygulama ve sonuçlar. Yayınlanmamış araştırma raporu.

Yeşilyaprak, B. ve ark. (2005). 2004-2005 öğretim y1lı oryantasyon programı: değerlendirme raporu.Yayınlanmamış araştırma raporu. Ankara Üniversitesi Eğitim Bilimleri Fakültesi.

Yeşilyaprak, B. ve Kısaç, İ. (2002). Yükseköğretimde bir oryantasyon programı: Uygulama ve değerlendirme. XII. Ulusal Psikoloji Kongresi, 9-13 Eylül, Ankara:ODTÜ.

Yeşilyaprak, B. (2003). Eğitimde Rehberlik Hizmetleri. Ankara:Nobel Yayın Dağıtım. 